The objective of BASELINE is to publish short communications for the concentration and distribution of elements and compounds in the marine environment. Only those papers which clearly identify the quality of the data will be considered for publication. Contributors to Baseline should refer to 'Baseline-A Record of Contamination Levels' (Mar. Pollut. Bull. 13, 217-218).

\section{Mercury Near a Caustic Soda Plant at Karwar, India}

$180 \mathrm{t}$ of mercury are introduced into the Indian environment every year of which $166 \mathrm{t}$ come from 38 caustic soda plants, including 23 units of mercury cell electrolysers of seawater (Choudhuri, 1980). Mercury levels in the Indian marine environment has been estimated by several workers and found to be within the safe limits except for certain identified 'hot spots' (Kureishy et al., 1979; Zingde \& Desai, 1981; Patel \& Chandy, 1988; Sanzigiri et al., 1988).

A caustic soda factory on the west coast of India, commissioned in 1975, is situated south of Karwar (Fig. 1). The effluents from the factory are discharged into Binage Bay which is well known for its mackerel fishery. Mass fish mortality was reported from this area in 1975 due to the high residual chlorine content of water (Annigeri, 1977).

Some studies involving periodic surveys have already been reported from this area (Kureishy et al., 1987), but details of mercury levels in the seawater, sediment and biota near the plant have not been reported. High concentrations of mercury has been reported in seawater off Karwar (Sanzigiri et al., 1988). The present study was initiated to understand the distribution of mercury and its impact on the marine ecosystem on the Karwar coast. This included monitoring of seawater, sediment, seaweeds, mussels and oysters in and around the impact area. In addition, varieties of pelagic fish and shell fish from commercial landings at Karwar were also monitored for mercury.

Water samples were collected from surface and bottom, from four stations near the discharge point in February 1989. Mercury was determined after a preconcentration step (Gardner \& Riley, 1974). For sampling sediment and biota, time bulking method (Phillips \& Segar, 1986) was used. Surface sediment samples were collected from 10 stations (Fig. 1) using a Peterson grab in September 1987-May 1988. The sediment samples were dried at $50^{\circ} \mathrm{C}$ and digested with $\mathrm{H}_{2} \mathrm{SO}_{4}$ and $\mathrm{HNO}_{3}$ mixture.

Mussels (Perna viridis), oyster (Crassostrea cucullata) and seaweed (Sargassum tenerimum) were sampled from 12 stations along the Karwar coast in September 


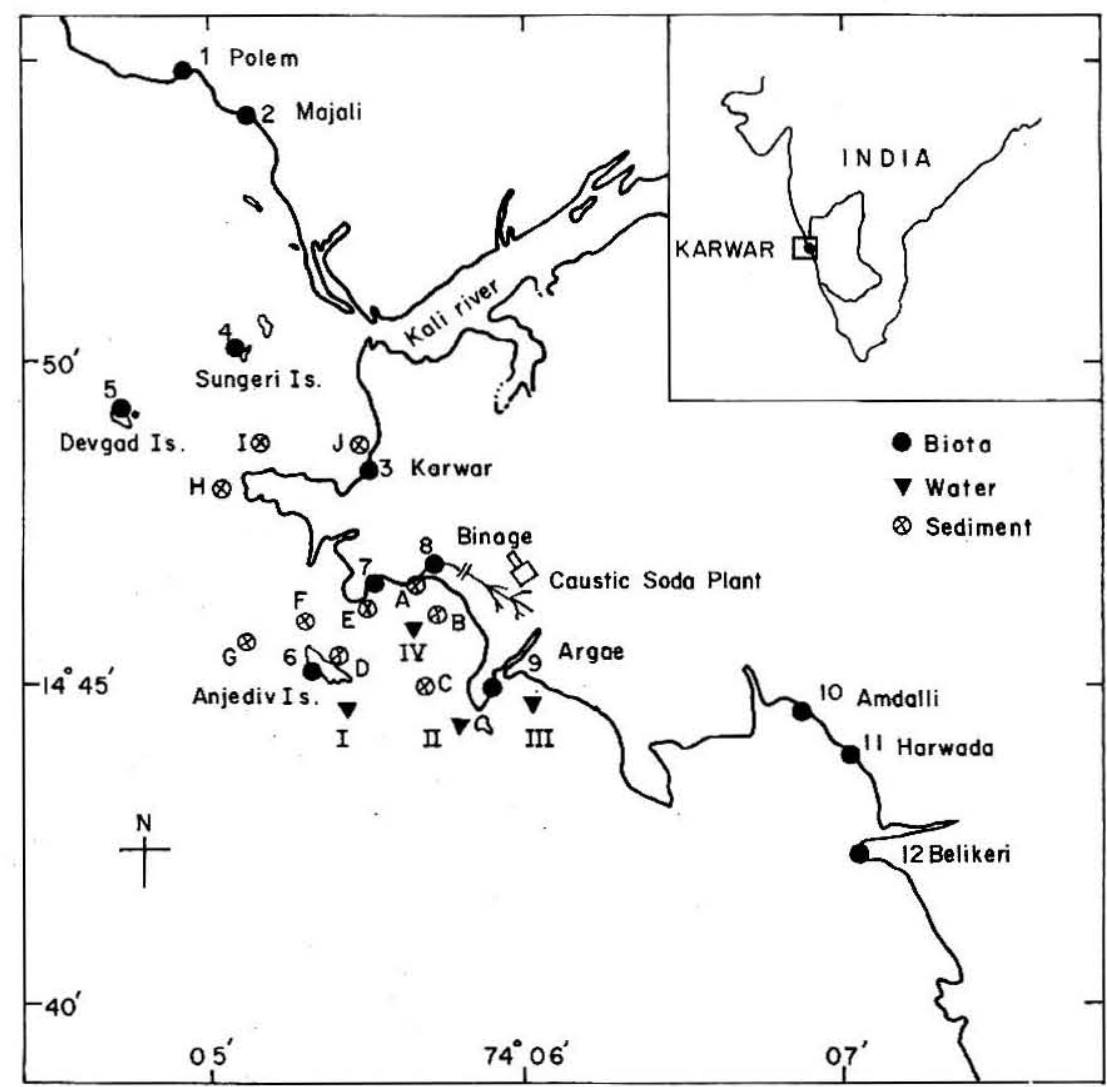

Fig. 1 Map of the study area showing sampling locations for water (samples 1-4), sediment (samples A-J) and biota (samples 112).

1987-February 1989 (Fig. 1) as determined by availability.

Fish, prawn, crab, and squid samples were collected from the commercial landings at Karwar. Soft tissues of mussels and oysters and the muscle of fish, prawn, crab and squid samples were analysed for mercury. Epiphytes of the seaweeds were removed and the entire green portion above the basal part was analysed for mercury. Biological samples were wet digested using $\mathrm{HNO}_{3}$ and $\mathrm{H}_{2} \mathrm{O}_{2}$ mixture (Dalziel \& Baker, 1983). All the digested samples were analysed for mercury by cold vapour atomic absorption technique using a mercury analyser, (ECIL).

The accuracy of the analytical procedure was checked using standard reference materials (lobster hepatopancreas) of the NRC Canada and found to be within $\pm 10 \%$ of their specified concentrations. Repeated digestion and analysis of the same samples were carried out to estimate the precision of the analysis. Percentage recovery of mercury from the samples were estimated with added mercuric chloride (Table 1).

The mercury concentrations in water collected from four stations are shown in Table 2. Mercury concentration was found to be higher in the vicinity of the discharge point $\left(0.91-2.62 \mu \mathrm{g} \mathrm{1^{-1 }}\right)$. The average value of mercury in the Arabian Sea is $0.061 \mu \mathrm{g} \mathrm{l}^{-1}$ (Sanzigiri et al., 1988). Mercury concentration was found to be higher in the surface water than in the bottom samples (Table 2). Similar observations were reported by earlier workers (Kureishy et al., 1987).

Mercury concentrations in the sediment samples collected from 10 stations are given in the Table 3. Near the discharge point, concentrations were comparatively high. High mercury levels were also reported in the sediment samples collected from the vicinity of industrial discharge zones from Bombay coast and Western Bay of Bengal (Patel \& Chandy, 1988; Sasamal et al., 1987).

Mercury concentrations in fish, prawn, crab and squid samples (Table 4) are comparable with the values reported for these species from the Indian coast (Sanzigiri et al., 1988). The mackerel Rastrelliger kanagurta

TABLE 1

Precision (coefficient of variation) and percentage recovery of mercury analysis.

\begin{tabular}{lcc}
\hline Sample & Precision & Percentage recovery \\
Seawater & $4 \%$ & 99 \\
Sediment & $10 \%$ & 91 \\
Biological tissue & $6 \%$ & 95 \\
\hline
\end{tabular}

TABLE 2

Total mercury in the seawater* collected from the vicinity of discharge point of the Caustic Soda factory, $\operatorname{Karwar}(\overline{\mathrm{x}} \pm \mathrm{SD}, \mathrm{N}=3)$.

\begin{tabular}{lcc}
\hline Station No. & $\begin{array}{c}\text { Depth } \\
\mathrm{m}\end{array}$ & $\begin{array}{c}\text { Total mercury } \\
\mu \mathrm{g} \mathrm{l}\end{array}$ \\
1 & 0 & $1.49 \pm 0.22$ \\
& 18 & $1.06 \pm 0.07$ \\
2 & 0 & $2.62 \pm 0.20$ \\
3 & 10 & $0.91 \pm 0.12$ \\
& 0 & $1.43 \pm 0.15$ \\
4 & 9 & $1.05 \pm 0.20$ \\
& 0 & $0.99 \pm 0.14$ \\
\hline
\end{tabular}

${ }^{*}$ Total $=$ dissolved + particulate. 
had higher mercury concentration than sardine, prawns, crab and squid, probably due to its carnivorous food habit and the linkage in the food chain.

Mercury concentration in oysters, mussels and seaweeds sampled from the Karwar coast is shown in Fig. 2 . In bivalves and seaweeds collected from the vicinity of discharge point (stations 5-8) mercury levels were found to be comparatively high $\left(0.06-0.314 \mu \mathrm{g} \mathrm{g}^{-1}\right)$. Stations 1 and 2 were found to be comparatively unpolluted areas. The sequence of mercury levels observed in the biota studied is as follows:

$$
\begin{aligned}
\text { sardine } & <\text { squid }<\text { crab }<\text { prawn }<\text { mackerel } \\
& <\text { seaweed }<\text { mussel }<\text { oyster }
\end{aligned}
$$

The green mussel $P$. viridis has been proposed as a biomonitor of heavy metals in tropical waters (Phillips, 1985). The present study shows that $C$. cucullata and $P$. viridis can be used as suitable bio-indicators of mercury contamination in the coastal environment (Fig. 2).

Before the construction of the present submarine effluent pipeline, the discharge went directly into a stream which originates from the factory site and flows into the sea (Annigeri, 1977). The oysters collected from this stream (Stn 8) showed a very high concentration of mercury. Earlier workers also reported high mercury levels in the water and sediment collected from the stream (Kureishy et al., 1987). The results of the present study show the same trend indicating that mercury may still be continuing to reach the stream (Fig. 2).

Mercury concentrations observed in the biota in the

TABLE 3

Total mercury concentration in the sediment samples collected from the coastal water of $\operatorname{Karwar}(\overline{\mathrm{x}} \pm \mathrm{SD}, \mathrm{N}=3)$.

\begin{tabular}{lcc}
\hline Station & Description of sediment & $\begin{array}{l}\text { Total mercury } \\
\mu \mathrm{gg}^{-1} \mathrm{dry} w \mathrm{wt}\end{array}$ \\
$\mathrm{A}$ & Sand & $0.10 \pm 0.01$ \\
$\mathrm{~B}$ & Mud & $1.14 \pm 0.04$ \\
$\mathrm{C}$ & Mud & $1.30 \pm 0.01$ \\
$\mathrm{D}$ & Sand & $0.01 \pm 0.005$ \\
$\mathrm{E}$ & Mud & $0.007 \pm 0.001$ \\
$\mathrm{~F}$ & Mud & $0.023 \pm 0.007$ \\
$\mathrm{G}$ & Mud & $0.053 \pm 0.01$ \\
$\mathrm{H}$ & Mud & $0.018 \pm 0.008$ \\
$\mathrm{I}$ & Mud & $0.122 \pm 0.005$ \\
$\mathrm{~J}$ & Sand & $0.002 \pm 0.001$ \\
\hline
\end{tabular}

present study are well within the safe limit of $0.5 \mu \mathrm{g} \mathrm{g}^{-1}$ wet wt (Nauen, 1983).

The authors wish to record their sincere thanks to Dr. P. S. B. R. James, Director, C.M.F.R. Institute, Cochin, for entrusting them to carry out investigations and for publishing the results. They are also grateful to Mr. M. S. Rajagopal, Head of F.E.M. Division and Mr. M. H. Dhulkhed, Officer-in-Charge, Karwar Research Centre of C.M.F.R. Institute, Karwar for their encouragement.

\section{P. K. KRISHNAKUMAR*} V. K. PILLAI

\section{Central Marine Fisheries Research Institute,}

P.B. No. 2704,

Cochin, 682 031, India

*Present address: Karwar Research Centre of C.M.F.R. Institute, P.B. No. 5, Karwar 581 301, India.

Annigeri, G. G. (1977). Study on the industrial waste discharged by the Caustic Soda factory of M/s Ballarpur Industries Ltd., Binaga, Near Karwar (India) and their probable effects on fauna dwelling in the area. 5th FAO/SIDA workshop on Aquatic Pollution in relation to protection of living resources. Manila, Philippines.

Chaudhuri, N. (1980). Increasing danger of mercury pollution. Ind. Exp. 48,9.

Dalziel, J. \& Baker, C. (1983). Analytical methods for measuring metals by atomic absorption spectrophotometry. FAO Fish Tech. Pap. 212, 14-20.

Gardner, R. \& Riley, J. P. (1974). Mercury in the Atlantic around Iceland. J. Cons. Inst. Explor. Mer. 35, 202-204.

Kureishy, T. W., George, M. D. \& Sengupta, R. (1979). Total mercury content in some marine fish from the Indian Coast. Mar. Pollut. Bull. 10, 357-360.

Kureishy, T. W., Mesquita, A. M. \& Sen Gupta, R. (1987). Mercury concentration in and around Binage Bay, Karwar, India. In Felicitation Volume for Dr. S. Z. Qasim 60th Birthday. Dec. 1987, pp. 347353.

TABLE 4

Mercury concentration in fish and shellfish sampled from the commercial landing at Karwar $(\tilde{x} \pm S D, N=5)$.

\begin{tabular}{lr}
\hline Species & $\begin{array}{r}\text { Total mercury } \\
\mu \mathrm{g} \mathrm{g}^{-1} \text { wet wt. }\end{array}$ \\
$\begin{array}{l}\text { Fish } \\
\text { Sardinella longiceps } \\
\text { Rastrelliger kanagurta }\end{array}$ & \\
Crab & $0.003 \pm 0.001$ \\
Portunas pelagicus & $0.03 \pm 0.004$ \\
Prawn & \\
Penaeus merguensis & $0.01 \pm 0.001$ \\
Parapenacopsis stylifera & \\
Squid & $0.01 \pm 0.001$ \\
Loligo duvaucelli & $0.01 \pm 0.001$ \\
\hline
\end{tabular}

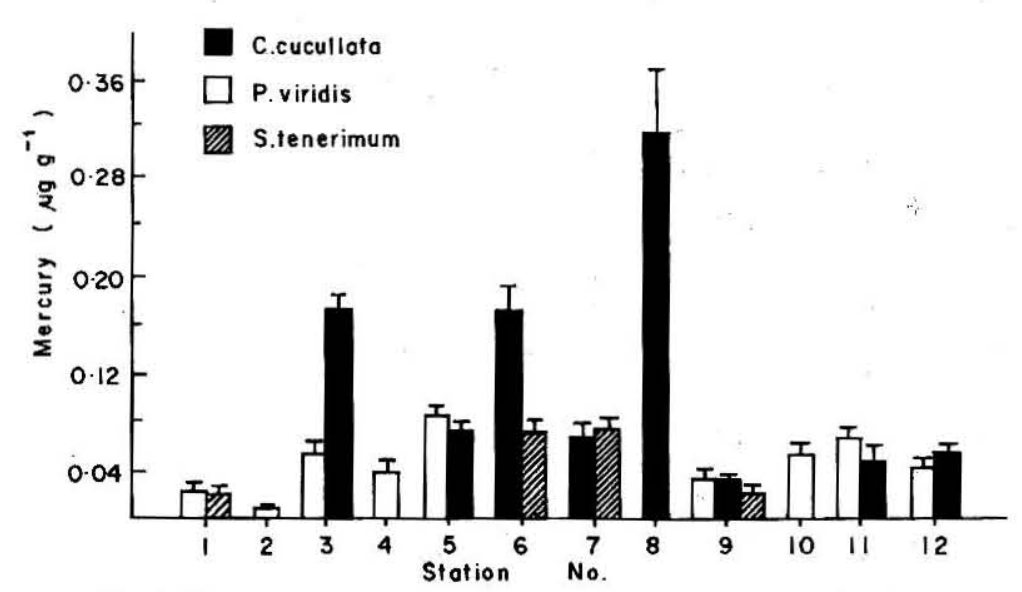

Fig. 2 Mercury concentration ( $\mu \mathrm{g} \mathrm{g}^{-1}$ wet wt $(\overline{\mathrm{x}} \pm \mathrm{SD}, \mathrm{N}=5)$ in Crassostrea cucullata. Perna viridis and Sargassum tenerimum collected from the coastal waters of Karwar. 
Nauen, C. E. (1983). Compilation of legal limits for hazardous substances in fish and fishery products. FAO Fish Circ. 764.

Patel, B. \& Chandy, J. P. (1988). Mercury in the biotic and abiotic matrices along Bombay Coast. Indian J. Mar. Sci. 17, 55-58.

Phillips, D. J. H. (1985). Organochlorines and trace metals in green lipped mussels Perna viridis from Hong Kong waters: a test of indicator ability. Mar. Ecol. Prog. Ser. 21, 252-258.

Phillips, D. J. H. \& Segar, D. A. (1986). Use of Bioindicators in monitoring Conservative Contaminants. Programme design imperatives. Mar. Pollut. Bull. 17, 10-17.

Sanzigiri, S., Mesquita, A. M. \& Kureishy, T. W. (1988). Total mercury in water, sediment and animals along the Indian Coast. Mar. Pollut. Bull. 19, 339-343.

Sasamal, S. K., Sahu, B. K., \& Panigrahy, R. C. (1987). Mercury distribution in the Estuarine and Nearshore sediments of the Western Bay of Bengal. Mar. Pollut. Bull. 18, 135-136.

Zingde, M. D. \& Desai, B. N. (1981). Mercury in Thana Creek, Bombay harbour. Mar. Pollut. Bull. 12, 237-241. 